\title{
Defining an Efficient Model for Inducing Obesity and Metabolic Syndrome in Wistar Rats
}

\author{
G. T. Adedeji ${ }^{12^{\star}}$, A. A. Fasanmade ${ }^{3}$ and E. O. Olapade-Olaopa ${ }^{2,4}$ \\ ${ }^{1}$ Department of Physiology, School of Health and Health Technology, Federal University of \\ Technology, Akure, Nigeria. \\ ${ }^{2}$ PIUTA Ibadan Centre, Department of Surgery, University of Ibadan, University College Hospital, \\ Ibadan, Nigeria. \\ ${ }^{3}$ Department of Physiology, University of Ibadan, Nigeria. \\ ${ }^{4}$ Division of Urology, Department of Surgery, College of Medicine, University of Ibadan, Nigeria.
}

\begin{abstract}
Authors' contributions
This work was carried out in collaboration between all authors. Author GTA designed the study, performed the statistical analysis, wrote the protocol and wrote the first draft of the manuscript. Authors AAF and EOOO managed the analyses of the study. Author EOOO managed the literature searches. All authors read and approved the final manuscript.

Article Information

DOI: $10.9734 / J A B B / 2017 / 33981$

(1) Andrzej Kowalski, Department of Biochemistry and Genetics, Institute of Biology, Jan Kochanowski University, Kielce, Poland.

Reviewers:

(1) Gado Dramane, Université de Parakou, Nigeria.

(2) Erika C. O. Naliato, Teresopolis Medical Association, Brazil.

(3) Samuel Grossman, City University of New York, USA.

(4) Azza Mohamed Elamir, Fayoum University, Egypt.

Complete Peer review History: http://www.sciencedomain.org/review-history/19747
\end{abstract}

Original Research Article

Received $7^{\text {th }}$ May 2017

Accepted $29^{\text {th }}$ May 2017

Published $28^{\text {th }}$ June 2017

\section{ABSTRACT}

Obesity and metabolic syndrome are major health problems which often present a confounding therapeutic challenge. Gene-nutrient interactions are implicated in metabolic phenotypes like Metabolic Syndrome, and rats have been used extensively to study them. However, different models have been stated in literature. The aim of this study was to explore different models and determine the most efficient model(s) of achieving diet-induced metabolic syndrome in wistar rats. Wistar rats $(n=208)$ weighing 100-120 g were used in this study. Rats were divided into gender pairs of 4 diets: standard rats' chow, standard rats' chow $+60 \%$ sucrose, high-fat (60\% margarine) and high-fat $(60 \%$ butter) and fed for nine (9) weeks. Body-mass Index (BMI), blood glucose, lipid profile, and insulin concentration were determined using standard methods. Male rats fed on HFD (butter) 
showed increases in all components of MS (Glucose $=161.2 \pm 0.8 \mathrm{mg} / \mathrm{dl}$, Insulin=800 $\pm 69 \mathrm{pmol} / \mathrm{l}$, total cholesterol $=96 \pm 3.2 \mathrm{mg} / \mathrm{dl}$ ). Male rats fed on a high fat diet are the most efficient means of creating diet-induced obesity and metabolic syndrome in Wistar rats.

Keywords: Wistar rats; diet obesity; metabolic syndrome; anthropometrics; animal models

\section{INTRODUCTION}

Obesity has been described as "the sixth most important risk factor in terms of the number of deaths in the world" [1]. It is a disorder caused by excessive calorific intake [2] and characterized by increased lipid storage in increasing numbers of adipocytes, and general expansion of adipose tissue itself [3]. It modifies both endocrine and metabolic roles played by adipose tissue [3] and is also a major risk factor for metabolic disorders including metabolic syndrome, Type II diabetes mellitus, atherosclerosis, dyslipidemia, hepatosteatosis, hypertension etc [4]. On the whole, even though obesity and excessive adiposity are associated with metabolic and cardiovascular disorders, the particular location of body fat distribution has been shown to be a greater factor in predisposition to metabolic and cardiovascular health risk [5].

In humans, as well as in rodent models, the particular phenotype manifested is a function of interactions between individual genes and environmental influences, including epigenetic ones [6]. Since the constitution of the gene is normally unchanged, alterations in the local environment is the easiest means of manipulating or influencing the phenotype. These alterations are used in designing experimental phenotypes for use in laboratory study of animals, mimicking the phenotypes as observed in humans. Recent findings in nutritional science research have shown that diet is a potent environmental factor capable of influencing the phenotype of an animal [7]. Diet is a common influence in humans and is a means of inducing metabolic phenotypes which closely-resemble that in humans, without pharmacological or genetic manipulations. Rats are often utilised in animal models for studying metabolic conditions like obesity and metabolic syndrome [8.9], and both humans and rodents tend to gain weight with high-caloric intake [10]. However, it has been observed that under ad libitum feeding conditions, not all experimental rats will eventually manifest the obese metabolic phenotype [11].
In experimental studies, obesity is usually defined as any "significant increase in body weight or energy content" in comparison with control animals under the same conditions in the study [12]. This definition is dependent on the assumption that control animals used in the laboratory for research are lean and normal, thus many observations reveal variability in incidence, onset time and severity of many of the metabolic conditions and degenerative diseases. This study was carried out to determine the most efficient means of developing a high calorific diet which would induce obesity in Wistar rats, using the least possible number of animals and the shortest possible duration of feeding.

\section{MATERIALS AND METHODS}

\subsection{Feed Composition}

Animal feeds were mixed from individual constituents in particular compositions for each of the dietary groups. The mixes were then pelletised to ensure even distribution of components and consumption by animals. The control diet was derived from standard rats' feeds commercially-propounded and sold by Ladokun feeds ${ }^{\circledR}$. Adequate nutritional requirements were ascertained and essential amino acids were added to the feeds to prevent under-nutrition. Feeds were subjected to bomb calorimetry to determine calorific content and analysed for appropriate macronutrient content by a nutritionist.

\subsection{Animals}

A total of 48 albino rats (24 males and 24 females) of the Wistar strain were used in this study. The animals were obtained from the Animal House of the College of Medicine, University of Ibadan, Nigeria. All studies were approved by the University of Ibadan Animal Ethics Committee. Handling and use of animals in this study were in accordance with the guiding principles for research involving animals as recommended by the declaration of Helsinki and the Guiding principles in the care and use of animals [13]. Animals were divided into pairs of 4 groups of 6 animals each and housed in well- 
aerated experimental animal cages, maintained under standard lighting conditions. They were acclimatised for 7 days prior to commencement of the grouping. During this period, they were fed on standard rat chow (Ladokun feeds, Nigeria Limited(B) and had access to clean drinking water.

\subsubsection{Animal groupings}

To achieve the overall aim, animals were divided into the following dietary groups, each with a male and a female component, and fed for nine (9) weeks:

- Group 1 (Control): Fed on normal rats' chow $(26.5 \%$ protein, $40 \%$ carbohydrates, $29 \%$ fat, and $4.5 \%$ crude fibre)

- Group 2: Fed on normal rats' chow + $60 \%$ sucrose-in-water solution

- Group 3: Fed on a High Fat diet (HFD) (22\% protein, $13.5 \%$ carbohydrates, $60 \%$ fat, and $4.5 \%$ crude fibre). Fat component was derived from margarine

- Group 4: Fed on a High Fat diet, however, fat component was derived from pure butter.

\subsubsection{Measurement of anthropometric variables}

Abdominal circumference (AC), Body length, and thoracic circumference (TC) were measured weekly using a tape measure. The abdominal circumference was measured immediately anterior to the hind-leg, body length was measured as nose-anus length, and thoracic circumference was measured immediately posterior to foreleg. These were used to determine the following:

$>$ Body mass index $(\mathrm{BMI})=$ body weight $(\mathrm{g}) /$ length $^{2}\left(\mathrm{~cm}^{2}\right)$.

$>$ Lee index $=$ cube root of body weight $(\mathrm{g}) /$ nose-to-anus length $(\mathrm{cm})[14]$.

\subsubsection{Determination of fasting blood glucose}

Fasting blood glucose was assessed by the use of a glucometer based on the glucose oxidase method of determination. Prior to assessing fasting blood glucose, the animals were fasted overnight, but were allowed free access to water [15].

\subsection{Lipid Profile}

Total cholesterol, triglycerides and HDLcholesterol were assessed in the serum of experimental animals. After the experimental period, animals were sacrificed and blood samples collected from them. The blood samples were centrifuged at $4^{\circ} \mathrm{C}$ for $20 \mathrm{~min}$ in a cold centrifuge and aliquots were then stored at $-20^{\circ} \mathrm{C}$ until assayed.

\subsubsection{Determination of total cholesterol}

The levels of total cholesterol in the treatment groups were determined using Randox kits. A method of enzyme hydrolysis as described by [16], and [17] was used.

\subsubsection{Determination of triacylglyceride concentration}

This was measured by colorimetric method as described by [18] and [19].

\subsubsection{Determination of HDL - cholesterol}

This was determined in the serum by the method of [20]. Randox HDL - cholesterol precipitant kit was used.

i. The precipitant kit contains phosphotungstric acid $(0.55 \mathrm{mmol} / \mathrm{l})$ and magnesium chloride $(25 \mathrm{mmol} / \mathrm{l})$

ii. Cholesterol content was determined using Randox kit reagent solution which is made up of 4 - aminoantipyrine $(0.3 \mathrm{mmol} / \mathrm{l})$, phenol $(\geq 6 \mathrm{~mol} / \mathrm{l})$, peroxidase $(\geq 0.5 \mathrm{u} / \mathrm{ml})$, cholesterol esterase $(\geq 0.15 \mathrm{u} / \mathrm{ml})$, pipe buffer $(80 \mathrm{mmol} / \mathrm{l}, \mathrm{pH} 6.8)$

\subsubsection{Plasma insulin determination}

This ELISA is a solid phase two-site enzyme immunoassay as described by [21]. It is based on the direct sandwich technique in which two monoclonal antibodies are directed against separate antigenic determinants on the insulin molecule. During incubation insulin in the sample reacts with anti-insulin antibodies bound to the microtitration well and with peroxidaseconjugated anti-insulin antibodies. A washing step removes unbound enzyme labeled antibody. The bound conjugate is detected by reaction with 3,3,5,5-tetramethylbenzidine (TMB). The reaction is stopped by adding acid to give a colorimetric endpoint that is read spectrophotometrically at a wavelength of $450 \mathrm{~nm}$ using a microplate reader. ELISA kits were procured from Sigma-Aldrich®.

\subsection{Statistical Analysis}

Data obtained were expressed as mean \pm standard error of mean (mean \pm SEM). The 
significance of the results was evaluated using analysis of variance (ANOVA) and the means were compared using Turkey-Kramer Multiple comparison Test. $\mathrm{P}<0.05$ was regarded as statistically significant.

\section{RESULTS}

\subsection{Effects of Different Diets on Anthropometric Variables}

The results indicate that by the $9^{\text {th }}$ week, Group 4 animals (fed on a high-fat diet derived from butter) showed significant increases in all anthropometric variables (Table 1). The males on that diet exhibited significant increases in body weight, thoracic and abdominal circumferences, $\mathrm{BMI}$ and Lee index $(\mathrm{P}<0.05)$ when compared with the control animals fed on the standard rats' chow. The females, however, exhibited an increase in abdominal circumference and Lee index only (Table 1). Group3 females (fed on a high-fat diet derived from margarine) only reflected an increase in Lee Index.

\subsection{Effect of Different Diets on Fasting Blood Glucose in Wistar Rats}

In individual comparison with the control, the results obtained show that fasting blood glucose was significantly elevated $(P<0.05)$ in Group 2 animals (fed on a normal rats' chow $+60 \%$ sucrose-in-water solution). In Group 4 animals (fed on a high fat diet derived from butter), both the male and female groups reflected a significant rise in fasting blood glucose (Table 2). However, this was a smaller increase when compared with that observed in Group 2 animals.

\subsection{Effect of Different Diets on Triglyceride Level in Wistar Rats}

Serum triglyceride concentration significantly $(\mathrm{P}<0.05)$ rose in Group 2 (fed on a normal rats' chow $+60 \%$ sucrose-in-water solution) male animals in comparison with control animals. Group 3 (fed on a high fat diet derived from margarine) and Group 4 (fed on a high fat diet derived from butter) male rats also exhibited significant increases in triglyceride level (Table 2). The greatest increase in triglyceride content was however observed in male animals fed on the high fat diet derived from butter.

\subsection{Effect of Different Diets on High Density Lipoprotein (HDL- Cholesterol) Level in Wistar Rats}

HDL-Cholesterol was significantly elevated $(\mathrm{P}<0.05)$ in Group 2 (fed on normal rats' chow + $60 \%$ sucrose-in-water solution) male rats in comparison with control animals. Group 4 (fed on a high fat diet derived from butter) male rats however had a decline in HDL-Cholesterol concentrations when they were compared with the control animals (Table 2).

Table 1. Anthropometric variables after $9^{\text {th }}$ week

\begin{tabular}{llllll}
\hline & $\begin{array}{l}\text { Body weight } \\
(\mathbf{g})\end{array}$ & $\begin{array}{l}\text { Thoracic } \\
\text { circumference } \\
(\mathbf{c m})\end{array}$ & $\begin{array}{l}\text { Abdominal } \\
\text { circumference } \\
\text { (cm) }\end{array}$ & $\begin{array}{l}\text { Body-mass } \\
\text { index }\end{array}$ & Lee index \\
\hline $\begin{array}{l}\text { Group 1 } \\
\text { males }\end{array}$ & $168.3 \pm 8.7$ & $10.500 \pm 0.300$ & $12.583 \pm 0.210$ & $0.38 \pm 0.01$ & $0.261 \pm 0.001$ \\
$\begin{array}{l}\text { Group 1 } \\
\text { females }\end{array}$ & $119.0 \pm 7.2$ & $9.250 \pm 0.158$ & $12.000 \pm 0.151$ & $0.31 \pm 0.01$ & $0.253 \pm 0.001$ \\
$\begin{array}{l}\text { Group 2 } \\
\text { males }\end{array}$ & $140.3 \pm 8.3$ & $9.929 \pm 0.213$ & $11.857 \pm 0.237$ & $0.34 \pm 0.01$ & $0.257 \pm 0.002$ \\
$\begin{array}{l}\text { Group 2 } \\
\text { females }\end{array}$ & $120.7 \pm 2.5$ & $9.000 \pm 0.109$ & $11.786 \pm 0.124$ & $0.33 \pm 0.01$ & $0.257 \pm 0.001$ \\
$\begin{array}{l}\text { Group 3 } \\
\text { males }\end{array}$ & $132.1 \pm 5.9$ & $9.111 \pm 0.105$ & $11.444 \pm 0.230$ & $0.35 \pm 0.01$ & $0.261 \pm 0.002$ \\
$\begin{array}{l}\text { Group 3 } \\
\text { females }\end{array}$ & $134.4 \pm 2.2$ & $9.000 \pm 0.141$ & $11.800 \pm 0.141$ & $0.37 \pm 0.01$ & $0.270 \pm 0.002^{*}$ \\
$\begin{array}{l}\text { Group 4 } \\
\text { males }\end{array}$ & $185.5 \pm 4.3^{*}$ & $13.000 \pm 0.100^{*}$ & $14.000 \pm 0.173^{*}$ & $0.46 \pm 0.02^{*}$ & $0.283 \pm 0.005^{*}$ \\
$\begin{array}{l}\text { Group 4 } \\
\text { females }\end{array}$ & $137.2 \pm 4.9$ & $10.100 \pm 0.071$ & $11.900 \pm 0.071^{*}$ & $0.40 \pm 0.02$ & $0.279 \pm 0.005^{*}$ \\
\hline
\end{tabular}

Values are mean \pm SEM for 6 animals per dietary group; $P=0.05$

${ }^{*}=$ significantly greater than control 


\subsection{Effect of Different Diets on Total Serum Cholesterol Level in Wistar Rats}

In Group 2 (fed on normal rats' chow $+60 \%$ sucrose-in-water solution) male animals, total serum cholesterol was significantly elevated $(\mathrm{P}<0.05)$ in comparison with the control animals. The Group 4 (fed on a high fat diet derived from butter) male animals also showed a significant increase in total cholesterol concentration, however the increase observed in Group 2 rats was greater (Table 2).

\subsection{Effect of Different Diets on Insulin Concentration in Wistar Rats}

Insulin concentration significantly $(\mathrm{P}<0.05)$ rose in Group 2 (fed on a normal rats' chow $+60 \%$ sucrose-in-water solution) male animals in comparison with control animals. Group 3 (fed on a high fat diet derived from margarine) and Group 4 (fed on a high fat diet derived from butter) male rats also exhibited highly significant increases in their serum levels of insulin (Table 2). The greatest increase in insulin content was however observed in male animals fed on the high fat diet derived from butter.

\section{DISCUSSION}

Dietary origins have been proposed to be the main factor responsible for the different metabolic phenotypes observed in animals and humans. The most common and most-studied of these phenotypes is that resulting in the metabolic syndrome (MetS), and this has been studied severally using various rodent models. Monogenic models, such as the ob/ob mouse or the fa/fa (obese Zucker) rat do not replicate the disease in humans suitably, as the syndrome in humans is polygenic [22]. Also, pharmacologic and drug-induced manipulations which induce MetS in animals (e.g. the gold-thioglucose mouse model) are unphysiologic and therefore not true representations of the human disease [22].

Numerous dietary models with varying macronutrient compositions have been used to induce metabolic syndrome in animals. It has been observed that the disorders achieved by high-fat feeding resemble the human metabolic syndrome closely, and this may also extend to the cardiovascular complications [23,24]. In rats, different models have been utilised by researchers to this same end, however, the results reported have been contrasting. It is however generally accepted that high-fat diets can be used to generate a valid rodent model for the metabolic syndrome with insulin resistance and compromised $\beta$-cell function $[25,26,27]$.

Many of these reports have described a sexrelated response to feeding on these MetS diets. This has been adduced to sex differences in adipose tissue distribution. Females generally

Table 2. Serum concentrations of MetS markers at the end of the $9^{\text {th }}$ week

\begin{tabular}{|c|c|c|c|c|c|}
\hline & $\begin{array}{l}\text { Fasting blood } \\
\text { glucose }(\mathrm{mg} / \mathrm{dL})\end{array}$ & $\begin{array}{l}\text { Serum } \\
\text { triglycerides } \\
\text { (mmol/l) }\end{array}$ & $\begin{array}{l}\text { HDL - } \\
\text { cholesterol } \\
\text { (mg/dl) }\end{array}$ & $\begin{array}{l}\text { Total serum } \\
\text { cholesterol } \\
\text { (mg/dl) }\end{array}$ & 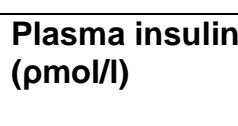 \\
\hline $\begin{array}{l}\text { Group } 1 \text { - } \\
\text { males }\end{array}$ & $99.8 \pm 0.4$ & $1.3 \pm 0.2$ & $33 \pm 0.8$ & $84 \pm 4.9$ & $512 \pm 78$ \\
\hline $\begin{array}{l}\text { Group } 1 \text { - } \\
\text { females }\end{array}$ & $99 \pm 0.5$ & $2.0 \pm 0.4$ & $28 \pm 0.3$ & $70 \pm 4.5$ & $522 \pm 31$ \\
\hline $\begin{array}{l}\text { Group } 2 \text { - } \\
\text { males }\end{array}$ & $184.7 \pm 0.7^{*}$ & $2.4 \pm 0.2^{*}$ & $39 \pm 1.4^{*}$ & $104 \pm 4.0^{*}$ & $767 \pm 68^{*}$ \\
\hline $\begin{array}{l}\text { Group } 2 \text { - } \\
\text { females }\end{array}$ & $181.6 \pm 0.8^{*}$ & $1.9 \pm 0.4$ & $30 \pm 1.8$ & $72 \pm 5.6$ & $548 \pm 74$ \\
\hline $\begin{array}{l}\text { Group } 3 \text { - } \\
\text { males }\end{array}$ & $115.8 \pm 0.4$ & $2.1 \pm 0.3^{*}$ & $32 \pm 1.2$ & $78 . \pm 3.5$ & $756 \pm 87^{*}$ \\
\hline $\begin{array}{l}\text { Group } 3 \text { - } \\
\text { females }\end{array}$ & $111.4 \pm 0.7$ & $2.2 \pm 0.1$ & $30 \pm 1.1$ & $71 \pm 5.8$ & $532 \pm 59$ \\
\hline $\begin{array}{l}\text { Group } 4 \text { - } \\
\text { males }\end{array}$ & $161.2 \pm 0.8^{*}$ & $2.9 \pm 0.2^{*}$ & $28 \pm 1.2^{*}$ & $96 \pm 3.2^{*}$ & $800 \pm 69^{*}$ \\
\hline $\begin{array}{l}\text { Group } 4 \text { - } \\
\text { females }\end{array}$ & $163.8 \pm 0.6^{*}$ & $2.2 \pm 0.2$ & $30 \pm 0.6$ & $73 \pm 6.2$ & $570 \pm 77$ \\
\hline
\end{tabular}


tend to have a higher adiposity throughout their lifespan in comparison to males $[28,29]$ whereas males have more central adiposity which is a greater predisposing factor for MetS [30]. The findings of this study reflect this sexual dimorphism as it was observed that generally the male animals had a greater elevation in anthropometric variables in intra-group comparisons with corresponding female groups. In addition, in the high-fat diet (butter) group which exhibited all the components of Mets, the female animals only showed an elevation in fasting blood glucose and abdominal circumference. All evidences from research point to the different sex hormones released in the sexes as responsible for this dimorphism [31].

High-fat diets typically used in research usually contain about 32 to $60 \%$ of calories from fat $[32,33]$. The high fat diets used in this study contained $60 \%$ of calories from fat derived from either margarine or butter. The extent of the metabolic disorder induced by a chosen diet depends on the dietary regimen utilised and the specific rodent strain than on the species itself. For example, C57BL/6J mice develop obesity and insulin resistance similar to Wistar rats, while 129S6 [34] or A/J mice [35] do not.

The results from the preliminary study suggest that of our four chosen MetS diets; only the male animals fed on the high-fat diet (butter) gave rise to all of the accepted variables that constitute MetS. This group was characterised by obesity, hyperglycemia, hypertriglyceridemia, low HDL cholesterol, and hyperinsulinemia. This is in consonance with studies which report that diets based on saturated fatty acids induce the typical high-fat-diet phenotype, whereas diets containing polyunsaturated $\omega-3$ fatty acids exert beneficial effects on body composition and insulin action [36]. The ability of a high-fat diet to induce obesity and MetS in animals has been adduced to energy density of the diet, rather than a purported increase in percentage of the dietary fat $[37,38,39,40,41]$. This corroborates the findings of this preliminary study as it was observed that although equal quantities of fat were fed to animals in both high fat diets (butter and margarine), only the HFD (butter) group showed significant effects in all MetS components. Butter is high in saturated fat content, while margarine contains trans-fatty acids. Trans-fatty acids are polyunsaturated fatty acids derived from partial hydrogenation of vegetable oils which are implicated in coronary heart disease and arteriosclerosis. Trans-fatty acids reduce serum levels of HDL cholesterol and increase the levels of LDL cholesterol while serum cholesterol levels also increase with higher intake of saturated fats and cholesterol. Higher intake of trans-fats or saturated fats has been shown to be associated with increase drisk of MetS and coronary heart disease [42].

In male animals given the $60 \%$ sucrose-in-water solution, a significant increase in all MetS variables was also observed but there was no significant change in body weight and an elevation of HDL cholesterol, which negated a true MetS picture. It has been reported that an increased intake of refined carbohydrates, such as sucrose (composed of fructose and glucose), is associated with increased weight gain, hypertriglyceridemia, and insulin resistance (IR) in both humans and also in animal models $[43,44]$. In rodent models, diets containing high sucrose elevate triglyceride and glucose production in the liver, thus increasing availability of nutrients and ultimately leading to $I R$ and hypertriglyceridemia [43,44]. The Wistar rat is an established model of sucrose-induced IR and hypertriglyceridemia $[45,46,47]$. It seems that the fructose component of sucrose is largely responsible for the hypertriglyceridemia and IR produced by high sucrose diets $[48,49,50]$. Chicco and co-workers observed that high sucrose diets do not appear to lead to excessive weight gain. This observation is corroborated by the findings in this study [51].

\section{CONCLUSION}

In deriving a most-efficient diet-induced model of MetS, a dietary formulation of pelletised high-fat diet with the fat component derived from pure butter is most ideal in producing results within the shortest possible time-frame. This diet gives rise to all the defining components of MetS, however, male rats are more likely to give the desired results due to their development of abdominal obesity.

\section{ACKNOWLEDGEMENTS}

Funding for this work was provided by PIUTA Ibadan Centre, College of Medicine, University of Ibadan and University College Hospital, Ibadan, Nigeria.

\section{COMPETING INTERESTS}

Authors have declared that no competing interests exist. 


\section{REFERENCES}

1. Rosiek A, Frąckowiak Maciejewska N, et al. Effect of television on obesity and excess of weight and consequences of health. Tchounwou $P$, ed. International Journal of Environmental Research and Public Health. 2015;12(8):9408-9426.

2. Gawęcki J, Gerting H. Nutritional definitions dictionary. PWN; Warsawa, Poland; 2001.

3. Coelho M, Oliveira $T$, Fernandes $R$. Biochemistry of adipose tissue: An endocrine organ. Archives of Medical Science : AMS. 2013;9(2):191-200.

DOI: 10.5114/aoms.2013.33181

4. Jung UJ, Choi MS. Obesity and its metabolic complications: The role of adipokines and the relationship between obesity, inflammation, insulin resistance, dyslipidemia and nonalcoholic fatty liver disease. International Journal of Molecular Sciences. 2014;15(4):6184-6223.

DOI: $10.3390 / \mathrm{ijms} 15046184$

5. Kaur J. A comprehensive review on metabolic syndrome. Cardiology Research and Practice. 2014;2014:943162.

DOI: $10.1155 / 2014 / 943162$

6. Institute of medicine (US) committee on assessing interactions among social, behavioral, and genetic factors in health; Hernandez LM, Blazer DG, editors. Genes, behavior, and the social environment: moving beyond the nature/nurture debate. Washington (DC). National Academies Press (US). 2006;7. Animal Models. Available:https://www.ncbi.nlm.nih.gov/boo ks/NBK19914/

7. Fenech M, El-Sohemy A, Cahill L, et al. Nutrigenetics and Nutrigenomics: Viewpoints on the current status and applications in nutrition research and practice. Journal of Nutrigenetics and Nutrigenomics. 2011;4(2):69-89.

DOI: $10.1159 / 000327772$

8. Lutz TA, Woods SC. Overview of animal models of obesity. Current protocols in pharmacology / editorial board, SJ Enna (editor-in-chief) [et al.]. 2012;5:61.

DOI: 10.1002/0471141755.ph0561s58

9. Wong SK, Chin K-Y, Suhaimi FH, et al. Animal models of metabolic syndrome: A review. Nutrition \& Metabolism. 2016; 13:65.

DOI: $10.1186 / \mathrm{s} 12986-016-0123-9$

10. Buettner R, Scholmerich J, Bollheimer LC. High-fat diets: Modeling the metabolic disorders of human obesity in rodents. Obesity (Silver Spring). 2007;15:798-808.

11. Sadowska J, Gębczyński AK, Konarzewski M. Metabolic risk factors in mice divergently selected for BMR fed high fat and high carb diets. Chowen JA, ed. PLoS ONE. 2017;12(2):e0172892.

DOI: 10.1371/journal.pone.0172892

12. Novelli ELB, Diniz YS, Galhardi CS. Anthropometrical parameters and markers of obesity in rats. Laboratory Animals. 2007;41:111-119.

13. World medical association. American physiological society. guiding principles for research involving animals and human beings. Am. J. Physiol. Reg. Integr. Comp. Physiol. 2002;283:281-283.

14. Bernardis LL. Prediction of carcass fat, water and lean body mass from Lee's nutritive ratio in rats with hypothalamic obesity. Experientia. 1970;26:789-90.

15. Yamaza H, Komatsu T, To K, Toyama H, Chiba T, Higami Y, Shimokawa I. Involvement of insulin-like growth factor-1 in the effect of caloric restriction: regulation of plasma ad ponectin and leptin. Journal of Gerontology: Biological Sciences. 2007; 62A(1):27-33.

16. Richmond W. Preparation and properties of a cholesterol oxidase from Norcadia sp. and its application to the enzymatic assay of total cholesterol in serum. Clin. Chem. 1973;19:1350-1356

17. Roeschlau P, Bernt E, Gruber W. Enzymatic determination of total cholesterol in serum. Z Klin Chem Klin Biochem. 1974;12(5):226.

18. Fossati $P$, Principe L. Serum triglycerides determined colorimetrically with an enzyme that produces hydrogen peroxide. Clin Chem. 1982;28(10):2077-80.

19. Young DS. Quantitative determination of triglycerides. In effects of drugs on clinical lab. Tests, 4th ed. AACC Press; 1995.

20. Jacobs DR, Jr, Mebane IL, Bangdiwala SI, Criqui $\mathrm{MH}$, Tyroler HA. High density lipoprotein cholesterol as a predictor of cardiovascular disease mortality in men and women: The follow-up study of the lipid research clinics prevalence study. Am J Epidemiol. 1990;131(1):32.

21. Engvall E, Perlmann P. Enzyme-limked immunosorbent assay (ELISA). Quantitative assay of immunoglobin $\mathrm{G}$. Immunochemistry. 1971;8(9):871-4.

22. Buettner R, Parhofer KG, Woenckhaus M, Wrede CE, Kunz-Schughart LA, 
Schölmerich J, Bollheimer LC. Defining high-fat-diet rat models: Metabolic and molecular effects of different fat types. Journal of Molecular Endocrinology. 2006; 36:485-501

23. Aguila MB and Mandarim-de-Lacerda CA. Heart and blood pressure adaptations in Wistar rats fed with different high-fat diets for 18 months. Nutrition. 2003;19:347-352.

24. Woods SC, Seeley RJ, Rushing PA, D'Alessio D, Tso P. A controlled high-fat diet induces an obese syndrome in rats. Journal of Nutrition. 2003;133:1081-1087.

25. Oakes ND, Cooney GJ, Camilleri S, Chisholm DJ, Kraegen EW. Mechanisms of liver and muscle insulin resistance induced by chronic high-fat feeding. Diabetes.1997;46:1768-1774.

26. Ahren B, Gudbjartsson T, Al Amin AN, Martensson $\mathrm{H}$, Myrsen-Axcrona $U$, Karlsson S, Mulder $H$, Sundler F. Islet perturbations in rats fed a high-fat diet. Pancreas. 1999;18:75-83.

27. Lingohr MK, Buettner R, Rhodes CJ. Pancreatic beta-cell growth and survival a role in obesity-linked type 2 diabetes? Trends in Molecular Medicine. 2002;8: 375-384.

28. Gallagher D, Visser M, Sepulveda D, Pierson RN, Harris T, Heymsfield SB. How useful is body mass index for comparison of body fatness across age, sex, and ethnic groups? American Journal of Epidemiology. 1996;143:228-239.

29. Jackson AS, Stanforth PR, Gagnon J, Rankinen T, Leon AS, Rao DC, Skinner JS, Bouchard C, Wilmore JH. The effect of sex, age and race on estimating percentage body fat from body mass index: The heritage family study. International Journal of Obesity And Related Metabolic Disorders: Journal of the International Association for the Study of Obesity. 2002;26:789-796.

30. Demerath EW, Sun SS, Rogers N, Lee M, Reed D, Choh AC, Couch W, Czerwinski SA, Chumlea WC, Siervogel RM, Towne B. Anatomical patterning of visceral adipose tissue: Race sex, and age variation. Obesity (Silver Spring). 2007; 15:2984-2993.

31. de Ridder CM, Bruning PF, Zonderland ML, Thijssen JH, Bonfrer JM, Blankenstein MA, Huisveld IA, Erich WB. Body fat mass, body fat distribution, and plasma hormones in early puberty in females. J Clin Endocrinol Metab. 1990;70:888-893.
32. Ghibaudi L, Cook J, Farley C, van Heek M, Hwa JJ. Fat intake affects adiposity, comorbidity factors, and energy metabolism of sprague-dawley rats. Obes Res. 2002;10:956-963.

33. Johnston SL, Souter DM, Tolkamp BJ, Gordon IJ, Illius AW, Kyriazakis I. Speakman JR. Intake compensates for resting metabolic rate variation in female C57BL/6J mice fed high-fat diets. Obesity (Silver Spring). 2007;15:600-606.

34. Almind $K$ and Kahn CR. Genetic determinants of energy expenditure and insulin resistance in diet-induced obesity in mice. Diabetes. 2004; 53 3274-3285.

35. Surwit RS, Kuhn CM, Cochrane C, McCubbin JA, Feinglos MN. Diet-induced type II diabetes in C57BL/6J mice. Diabetes. 1988;37:1163-1167.

36. Storlien LH, Higgins JA, Thomas TC, Brown MA, Wang HQ, Huang XF, Else PL. Diet composition and insulin action in animal models. British Journal of Nutrition. 2000;83:S85-S90.

37. Prentice AM. Manipulation of dietary fat and energy density and subsequent effects on substrate flux and food intake. Am. J. Clin. Nutr. 1998;67(Suppl. 3):535S-541S.

38. Rolls BJ, Shide D. Dietary fat and control of food intake. In: Appetite and body weight regulation: Sugar, fat and macronutrient substitutes (Fernstrom GD, Miller GD, eds.). CRC Press, Boca Raton, FL; 1994.

39. Poppitt SD. Energy density of diets and obesity. Int. J. Obes. 1995;19(Suppl.): S20-S26.

40. Stubbs RJ, Harbron CG, Prentice AM. Covert manipulation of the dietary fat to carbohydrate ratio of isoenergetically dense diets: Effect on food intake in feeding men ad libitum. Int. J. Obes. 1996; 20:651-660.

41. Prentice AM, Poppitt SD. Importance of energy density and macronutrients in the regulation of energy intake. Int. J. Obes. 1996;20(Suppl.):S18-S23.

42. Hu FB, Stampfer MJ, Manson JE, Rimm E, Colditz GA, Rosner BA, Hennekens $\mathrm{CH}$, Willett WC. Dietary fat intake and the risk of coronary heart disease in women. $\mathrm{N}$ Engl J Med. 1997;337:1491-9.

43. Daly ME, Vale C, Walker M, Alberti KG, Mathers JC. Dietary carbohydrates and insulin sensitivity: A review of the evidence and clinical implications. Am J Clin Nutr. 1997;66:1072-1085 
44. Basciano H, Federico L, Adeli K. Fructose, insulin resistance, and metabolic dyslipidemia. Nutr. Metab (Lond). 2005; 2:5.

45. Pagliassotti MJ, Prach PA, Koppenhafer TA, Pan DA. Changes in insulin action, triglycerides, and lipid composition during sucrose feeding in rats. Am J Physiol. 1996;271:R1319-R1326.

46. Thigpen JE, Setchell KD, Ahlmark KB, Locklear J, Spahr T, Caviness GF, Goelz MF, Haseman JK, Newbold RR, Forsythe DB. Phytoestrogen content of purified, open- and closed-formula laboratory animal diets. Lab Anim Sci. 1999;49:530536.

47. Pagliassotti MJ, Gayles EC, Podolin DA, Wei Y, Morin CL. Developmental stage modifies diet-induced peripheral insulin resistance in rats. Am J Physiol Regul. Integr. Comp Physiol. 2000;278:R66-R73.
48. Sleder J, Chen YD, Cully MD, Reaven GM. Hyperinsulinemia in fructose-induced hypertriglyceridemia in the rat. Metabolism. 1980;29:303-305.

49. Thorburn AW, Storlien LH, Jenkins AB, Khouri S, Kraegen EW. Fructose-induced in vivo insulin resistance and elevated plasma triglyceride levels in rats. Am J Clin Nutr. 1989;49:1155-1163.

50. Thresher JS, Podolin DA, Wei Y, Mazzeo RS, Pagliassotti MJ. Comparison of the effects of sucrose and fructose on insulin action and glucose tolerance. Am J Physiol Regul. Integr. Comp Physiol. 2000; 279:R1334-R1340.

51. Chicco A, D'Alessandro ME, Karabatas L, Pastorale C, Basabe JC, Lombardo YB. Muscle lipid metabolism and insulin secretion are altered in insulin-resistant rats fed a high sucrose diet. J Nutr. 2003; 133:127-133.

(c) 2017 Adedeji et al.; This is an Open Access article distributed under the terms of the Creative Commons Attribution License (http://creativecommons.org/licenses/by/4.0), which permits unrestricted use, distribution, and reproduction in any medium, provided the original work is properly cited.

Peer-review history:

The peer review history for this paper can be accessed here: http://sciencedomain.org/review-history/19747 